\title{
Production of Enzymes and
}

\section{Biotransformation of Orange Waste by Oyster Mushroom, Pleurotus pulmonarius (Fr.) Quél.}

\author{
Fabíola Dorneles Inácio ${ }^{1,2}$, Roselene Oliveira Ferreira², \\ Caroline Aparecida Vaz de Araujo², Rosane Marina Peralta2,3, \\ Cristina Giatti Marques de Souza ${ }^{2,3 *}$ \\ ${ }^{1}$ Federal Institute of Paraná-Campus Jacarezinho, Jacarezinho, Brazil \\ ${ }^{2}$ Post-Graduation Program of Biological Sciences, State University of Maringá, Maringá, Brazil \\ ${ }^{3}$ Departament of Biochemistry, State University of Maringá, Maringá, Brazil \\ Email: ${ }^{*}$ cgmsouza@uem.br
}

Received 25 November 2014; revised 10 December 2014; accepted 20 December 2014

Copyright (C) 2015 by authors and Scientific Research Publishing Inc.

This work is licensed under the Creative Commons Attribution International License (CC BY). http://creativecommons.org/licenses/by/4.0/

\section{Abstract}

The wood-decay fungi are able to bioconvert a wide variety of lignocellulosic residues due to the secretion of extracellular enzymes. The use of agricultural wastes as substrate for mushroom cultivation or enzymes production can help to solve environmental problems caused by inadequate discharge in the nature. The production of hydrolytic and oxidative enzymes by Pleurotus pulmonarius developed in solid state system using orange waste as substrate was evaluated in this work. Among the hydrolytic enzymes, pectinase was the main enzyme produced by the fungus, presenting the highest enzymatic activity of $9.4 \mathrm{U} / \mathrm{mL}$ after 35 days of cultivation. Considering the oxidative enzymes, laccase was the main enzyme produced with maximal activity of $12.2 \mathrm{U} / \mathrm{mL}$ obtained after 20 days of cultivation. Low enzyme levels of manganese peroxidase, $\beta$-glucosidase and $\beta$-xylosidase were detected with activity peaks at the end of the cultivation. The enzymatic levels of amylase, carboxymethyl cellulase and xylanase were similar and less than $1.5 \mathrm{U} / \mathrm{mL}$. No aryl-alcohol oxidase activity was detected. NDF, ADF and cellulose values increased during 45 days of cultivation. There was no lignin degradation during the study period and the fungus culture in orange solid waste caused protein enrichment in the substrate. Our results demonstrate that $P$. pulmonarius was an efficient producer of two important industrial enzymes, pectinase and laccase in a cheap solid state system using orange waste as substrate.

"Corresponding author.

How to cite this paper: Inácio, F.D., Ferreira, R.O., de Araujo, C.A.V., Peralta, R.M. and de Souza, C.G.M. (2015) Production of Enzymes and Biotransformation of Orange Waste by Oyster Mushroom, Pleurotus pulmonarius (Fr.) Quél. Advances in Microbiology, 5, 1-8. http://dx.doi.org/10.4236/aim.2015.51001 
Keywords

Orange Waste, Biotransformation, Pleurotus pulmonarius, Basidiomycetes

\section{Introduction}

The orange fruit is one of the widely produced and consumed fruits in the world. Its production exceeds 80 million tons a year. Around $34 \%$ of orange production is usually made into juice, however in countries where orange is widely produced (Brazil and the United States) this number rises to $96 \%$, generating a huge amount of citric residue (approximately 50\% of the total fruit weight), which may be potentially applied to biotechnology [1] [2].

There is a variety of white-rot fungi, most of which are basidiomycetes. The lignocellulolytic basidiomycetes are not only important decomposers, but also the main organisms responsible for recycling carbon in the ecosystems. They degrade the wood components, such as cellulose, hemicellulose and lignin, into low molecular weight components that can be assimilated for their growing and reproduction [3]. This capability is due to system consisted of lignocellulolytic enzymes, such as $\beta$-glucosidase, cellulase, xylanase, lignin peroxidase (LiP), manganese peroxidase (MnP) and laccase among others [4]-[6].

Many of the enzymes produced by the fungi are importantly applied to several industrial areas. Some of these applications are in the production of detergent, starch, beverages, food, textile industry, animal feed, pulp and paper, leather, chemical and biomedical products [3] [7]. There is a great number of non-pathogenic microorganisms capable of producing useful enzymes, however the filamentous fungi are highlighted for being easily cultivated and for the high production number of enzymes for industrial application [7] [8].

The genus Pleurotus includes species of white-rot fungi that have ability to degrade lignin, cellulose and hemicellulose of wood [9] due to the production of various enzymes, such as $\beta$-amylase, cellulase, xylanase, MnP and laccase [4] [10] [11]. The aim of this study was to obtain a profile of extracellular enzymes produced by Pleurotus pulmonarius (Fr.) Quélet in solid state fermentation (SSF) using orange waste as substrate.

\section{Materials and Methods}

\subsection{Organism and Culture Conditions}

P. pulmonarius (Fr.) Quél.-CCB20 was obtained from the Culture Collection of the Botany Institute of São Paulo. The stock culture of the fungus was maintained at $4{ }^{\circ} \mathrm{C}$ through periodical transfer in Petri dish containing wheat bran $(20 \mathrm{~g} / \mathrm{L})$, agar $(18 \mathrm{~g} / \mathrm{L})$ and mineral medium [12]. Orange (Citrus sinensis (L.) Osb.) residue was obtained at the local businesses in Maringá, Paraná, Brazil and consisted of orange pulp, including membrane tissue as well as peel, after extracting the juice (solid waste). The material was dried at $40^{\circ} \mathrm{C}$ and milled $(2 \mathrm{~mm})$.

The cultivation was carried out in Erlenmeyers flasks $(125 \mathrm{~mL})$ containing $4 \mathrm{~g}$ of orange waste and sufficient amounts of mineral media to obtain initial humidity of $85 \%$. Two mycelial plugs of agar plates containing 7 daymycelium, (15 $\mathrm{mm}$ in diameter) were used as inoculum after the instruments sterilization. The flasks were incubated at $28^{\circ} \mathrm{C}$ in the dark. Cultivation was interrupted at determined periods with the addition of $20 \mathrm{~mL}$ of distilled water, followed by agitation for $20 \mathrm{~min}$ at $8^{\circ} \mathrm{C}$, vacuum filtration and centrifugation $(10 \mathrm{~min} ; 10,000 \mathrm{~g}$; $4^{\circ} \mathrm{C}$ ). The supernatant was used as crude enzymatic solution. The material retained on the filter paper (Whatman $\mathrm{N}^{\circ}$ 1) was dried at $40^{\circ} \mathrm{C}$ and milled to obtain $1 \mathrm{~mm}$ particles and stored to determine the fibers, crude protein, lignin and cellulose.

\subsection{Enzymatic Activity}

\subsubsection{Hydrolytic Enzymes}

The xylanase (EC 3.2.1.8), $\alpha$-amylase (EC 3.2.1.1), pectinase (EC 3.2.1.5) and carboxymethyl cellulase (CMCase) (EC 3.2.1.4) activities were determined from the hydrolysis of their substrates at $1 \%(\mathrm{w} / \mathrm{v})$ : birchwood xylan, starch, pectin and carboxymethyl cellulose ([1] Alexandrino et al. 2007). The reducing sugar released were estimated by the 3,5-dinitrosalicylic acid method (DNS) [13].

The $\beta$-xylosidase (EC 3.2.1.37) and $\beta$-glucosidase (EC 3.2.1.21) activities were determined by the synthetic 
substrates $\rho$-nitrophenyl- $\beta$-D-xylopyranoside and $\rho$-nitrophenyl- $\beta$-D-glucopyranoside. The reaction was interrupted by the addition of a $\mathrm{Na}_{2} \mathrm{~B}_{4} \mathrm{O}_{7} \cdot 10 \mathrm{H}_{2}$ saturated solution [14]. All the reactions were performed at $40^{\circ} \mathrm{C}$ for $60 \mathrm{~min}$ and the enzymatic activities were expressed in international unities per milliliter $(\mathrm{U} / \mathrm{mL})$.

\subsubsection{Oxidative Enzymes}

The laccase (EC 1.10.3.2) activity was determined spectrophotometrically with 2,2'-Azino-bis[3-ethylbenzthiazoline-6-sulfonic] (ABTS) at $10 \mathrm{mM}$ as a substrate using acetate buffer $50 \mathrm{mM}(\mathrm{pH} 5.0)$, at $40^{\circ} \mathrm{C}$ for $5 \mathrm{~min}$. Oxidation of ABTS was monitored by the absorbance increase $\left(A_{420}=36,000 \mathrm{M}^{-1} \cdot \mathrm{cm}^{-1}\right)$ [15]. The MnP (EC 1.11.1.13) was determined by the oxidation of $\mathrm{MnSO}_{4} 10 \mathrm{mM}$, with $\mathrm{H}_{2} \mathrm{O}_{2} 0.5 \mathrm{mM}$ at $37^{\circ} \mathrm{C}$ for $5 \mathrm{~min}$ at $270 \mathrm{~nm}$ $\left(A_{270}=11.59 \mathrm{mM}^{-1} \cdot \mathrm{cm}^{-1}\right)[16]$. The aryl-alcohol oxidase (AAO) $(\mathrm{EC} 1.1 .3 .7)$ was estimated as oxidation of veratryl alcohol at $5 \mathrm{mM}$ to veratraldehyde $\left(A_{310}=9300 \mathrm{M}^{-1} \cdot \mathrm{cm}^{-1}\right)$ in phosphate buffer $100 \mathrm{mM}(\mathrm{pH} 6.0)$ [17].

The enzymatic activities were expressed in international unities per milliliter $(\mathrm{U} / \mathrm{mL})$. One unit of enzyme activity was defined as the amount of enzyme required to oxidize $1 \mu \mathrm{mol}$ of substrate per minute. The reagents used were from Sigma-Aldrich brand, USA.

\subsection{Total Phenolics and Antioxidant Activity Assay}

Total soluble phenolics in the cell free culture broth were colorimetrically estimated by the Folin-Ciocalteu method [18] and expressed as equivalent to the gallic acid. The antioxidant activity was measured in the presence of ABTS radicals [19].

\subsection{Substrate Characterization}

Neutral detergent fiber (NDF: cellulose, hemicellulose and lignin), acid detergent fiber (ADF: lignocellulose), lignin and cellulose were determined by the Van Soest method from the fermentation residual material [20]. The nitrogen content was estimated by the micro-Kjeldahl method [21]. Crude protein was measured by the nitrogen content $(\mathrm{N})$, using the conversion factor $\mathrm{N} \times 4.38$ [22].

\subsection{Statistical Analysis}

All the analysis was carried out in duplicate. The data was expressed as the means \pm standard deviations. Differences of $5 \%(p<0.05)$ among the means were considered significant according to Dunnett test. The results were analyzed using the Graph-Pad Prism 3.0 (San Diego, EUA) software.

\section{Results}

\subsection{Production of Enzymes by P. pulmonarius on Orange Waste Solid State Cultures}

The isolate of P. pulmonarius CCB20 was selected for the present study due to its capability to grow in orange residue. In previous experiments, the fungus was able to completely colonize orange waste at $85 \%$ initial moisture content after 8 days of cultivation at $28^{\circ} \mathrm{C}$. The time course of enzymes production by $P$. pulmonarius was followed for up to 45 days (Figure 1).

The pectinase activity maintained stable until the 20th cultivation day, with a mean of $6.2 \pm 0.60 \mathrm{U} / \mathrm{mL}$. After declining, the production increased on the 35th day, with a maximum value of $9.4 \pm 0.40 \mathrm{U} / \mathrm{mL}$ (Figure $1(\mathrm{~b})$ ). In the present study, $\beta$-glucosidase was detected at two peaks, with the maximum activity of $0.7 \pm 0.01 \mathrm{U} / \mathrm{mL}$, at the end of cultivation (Figure 1(c)).

There are two categories of enzymes which degrade hemicellulose: the endo- $\beta$-xylanases (EC 3.2.1.8.), which attack the xylan main chain, and the $\beta$-xylosidase (EC 3.2.1.3.7.), which hydrolyze xylooligosaccharides into D-xylose. The maximum xylanase and $\beta$-xylosidase acitivities were $0.7 \pm 0.02 \mathrm{U} / \mathrm{mL}$ and $0.3 \pm 0.03 \mathrm{U} / \mathrm{mL}$, respectively (Figure 1(d)).

The maximum CMCase and amylase activities were $0.6 \pm 0.05 \mathrm{U} / \mathrm{mL}$ and $1.1 \pm 0.06 \mathrm{U} / \mathrm{mL}$, respectively, on the fifth cultivation day (Figure 1(a)).

Laccase activity was high between the 12th to the 20th day, presenting the highest value of $12.2 \pm 0.15 \mathrm{U} / \mathrm{mL}$ on the 20th cultivation day (Figure 1(b)). The enzyme was produced despite the presence of reducing sugars; 


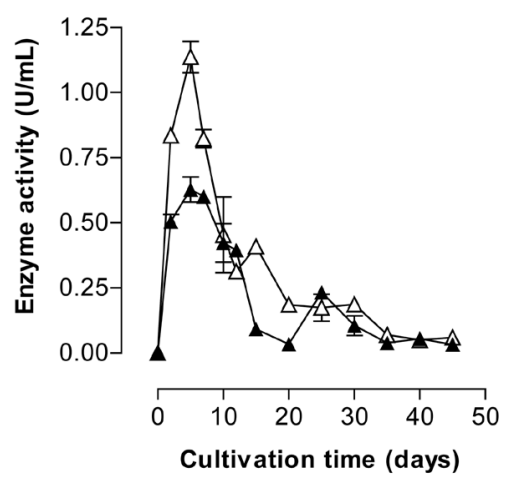

(a)

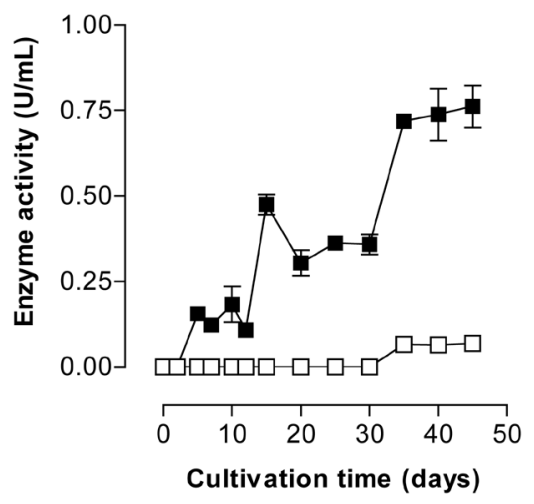

(c)

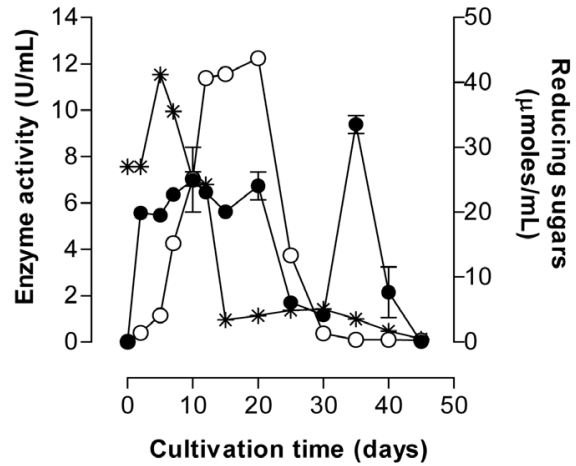

(b)

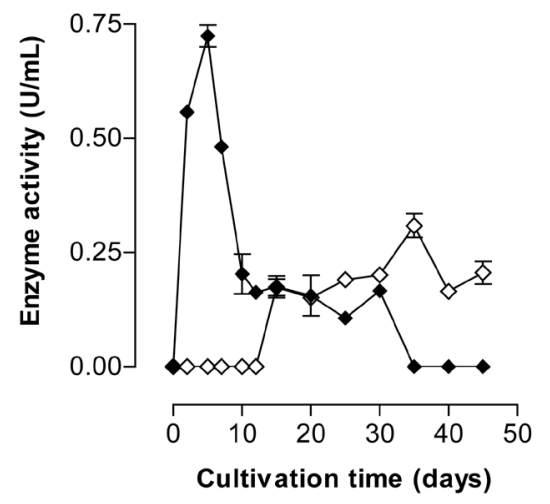

(d)

Figure 1. Time course of extracellular enzymes production by Pleurotus pulmonarius grown in orange waste in solid state fermentation. In (a) carboxymethyl cellulase $(\boldsymbol{\Delta})$ and amylase $(\Delta)$; in (b) pectinase (O), laccase (O) (left axis) and reducing sugars (*) (right axis); in (c) manganese peroxidase $(\square)$ and $\beta$-glucosidase $(\square)$; in $(d) \beta$-xylosidase $(\diamond)$ and xylanase $(\diamond)$.

Data are the mean \pm standard deviation of duplicate experiments.

however it reached its peak when the reducing carbohydrates decreased (Figure 1(b)).

Low MnP activities were found along the cultivation, with a maximum value of $0.07 \pm 0.00 \mathrm{U} / \mathrm{mL}$ on the last day (Figure 1(c)). No AAO activity was detected in this study.

\subsection{Substrate Biotransformation by $P$. pulmonarius}

Usually, dry orange waste contains up to $12 \%$ of crude fiber (including pectin and cellulose), $6 \%$ of protein, $7 \%$ of ash, $63 \%$ of nitrogen, $19 \%$ of total sugar and $9 \%$ of reducing sugar [23].

In this study, NDF, ADF and cellulose values increased (data not show), until the last cultivation day, suggesting the absence of consumption of these polymers by the fungus. There was no lignin degradation during the study period.

The fungi culture in orange solid waste caused protein enrichment in the lignocellulosic substrate. A significant increase $(p<0.01)$ in the substrate protein content was observed from the 7 th cultivation day, resulting in an addition of $4 \%$ until the last point of the growth curve.

In the present study there was a detected decrease in antioxidant activity of the crude extract, from $100 \%$ to $39 \%$, on the last cultivation day (Figure 2), evaluated by the ABTS radical assay.

\section{Discussion}

Byproducts obtained from citrus juice production are rich in soluble and insoluble carbohydrates, making them an attractive raw material with great potential for biologic conversion to value-added products [24]-[26]. Pectin is one the most abundant carbohydrates from orange waste. Although pectinolytic activity in wood-decomposing 


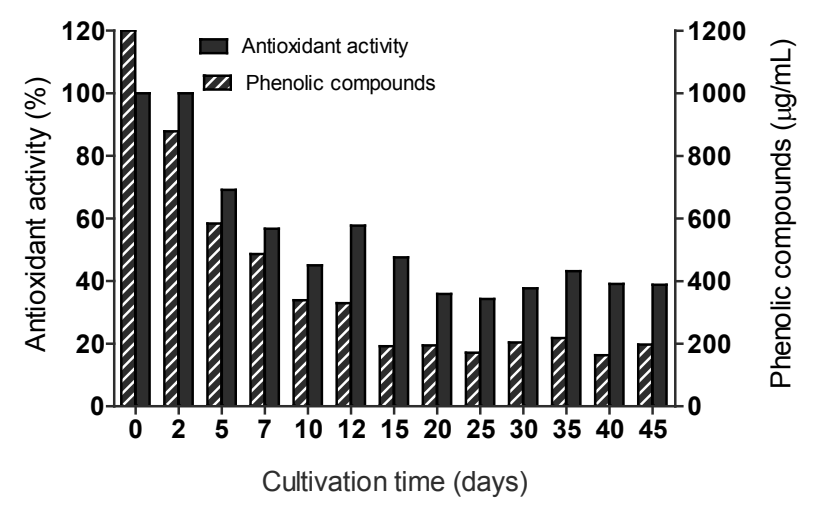

Figure 2. Total antioxidant activity and phenolic content of aqueous extracts of the cultivation of Pleurotus pulmonarius in orange waste.

fungi has been scarcely reported, recent studies demonstrate that pectinase may be produced by these fungi in lignocellulosic substrates, including citrus pulp [27] [28].

The enzymatic secretion responsible for carbohydrates cleavage, for example, pectinase and $\beta$-glucosidade, have been associated with lignin degradation [29], because oxidase and peroxidase actions in the cell wall, the polysaccharide intertwined with lignin polymer got more susceptible to degradation by hydrolases. This fact may explain the increase in the pectinase and $\beta$-glucosidase activities at the end of fermentation, concurrently with the MnP increase (Figure 1(b) and Figure 1(c)).

Studies have demonstrated that when Pleurotus spp. are cultivated under SSF in lignocellulosic substrates they are capable of producing cellulases, xylanases [30] phenoloxidases [15] and peroxidases [17]. However, it has been observed that this genus does not produce high xylanase and $\beta$-xylosidase activities [31] [32]. In large scale, xylanases are mainly produced by Aspergillus and Trichoderma ssp. [31].

Makkar et al. [33] reported that the $\beta$-glucosidase enzyme is part of an enzymatic complex in Lentinus edodes, which also comprises $\mathrm{MnP}$ and laccase, where the hydrolase actively participates in the carbohydrates mobilization. Lower activities of this enzyme were produced by $P$. ostreatus and $P$. sajor-caju cultivated in banana waste: $0.090 \mathrm{U} / \mathrm{mL}$ and $0.087 \mathrm{U} / \mathrm{mL}$, respectively [34]. P. pulmonarius produced CMCase and amylase at very low titers. Similar results were found by Sherief et al. [35] when cultivated $P$. ostreatus in rice straw.

The efficient lignin degradation carried out by the white-rot fungi mainly occurs through laccase, LiP and $\mathrm{MnP}$ secretion. Oyster mushrooms are well-known laccase and MnP producers, but no typical LiP [36].

The cellulose in the cultivation of $P$. sajor-caju increased whereas a linear decrease was observed for NDF but not for ADF content [37]. Considering that soluble carbohydrates were consumed during cultivation of $P$. pulmonarius probably cellulose, NDF and ADF had relative increase during culture period. Although the enzymes production was influenced by the substrate, the study conditions did not favored lignin, cellulose and hemicellulose degradation by P. pulmonarius. A similar result was observed by Levin et al. They were not found in correlation between high lignocellulolytic enzyme activities and lignin degradation [38]. Thus, the white-rot fungi capability of degrading wood seems to be related to the oxidative activities levels only after long periods of biodegradation [39].

The ligninolytic system of Pleurotus spp. has not been fully defined yet, however, there is evidence that it is different from the other white-rot fungi [40]. MnP seems to play a crucial role in the primary attack on lignin, as it produces $\mathrm{Mn}^{3+}$, a strong oxidant which attacks certain parts of the polymer [41]. Lignin degradation not only involves mediators, but also the enzymes synergistic action [42]. The metabolic role proposed for the AAO enzyme has been the offer of hydrogen peroxide $\left(\mathrm{H}_{2} \mathrm{O}_{2}\right)$ to be used by the peroxidases. The $\mathrm{H}_{2} \mathrm{O}_{2}$ may also be involved in ligocellusose degradation as the precursor of the hydroxyl radical $(\mathrm{OH} \cdot)$ a powerful oxidant agent [43]. Thus, the absence of AAO and low MnP activity found in the present study may have contributed to the nondegradation of the polymers in the cell wall, specially lignin, in the conditions in which they were studied.

Many researchers have demonstrated that the antioxidant activity of plants and mushrooms extracts is associated with the phenolic compounds extracted from these materials [24] [25]. The results obtained in this present study suggests that laccase promoted phenolic oxidation, being in accordance with the low levels of total phenolic compounds detected by the Folin method after many cultivation days (Figure 2). McCue et al. [29] de- 
tected a decrease of $85 \%$ in the antioxidant capability of the aqueous extract during the Lentinus edodes cultivation on the first 10 days, followed by a gradual increase until the 40th day. Furthermore, an increase of the phenolic compounds was detected over time, which was considered as a mobilization from the laccase enzymes and $\beta$-glucosidase.

Thus, the orange waste, besides demonstrating to be capable of inducing the production of pectinase and laccase by P. pulmonarius, also shows that its solid fermentation residual substrate has high potential to be used in the development of animal feed, enriched in its protein content lowering production costs as well as valorizing the residue from the citric industry.

\section{Conclusion}

Our results support the use of orange waste as substrate for production of important industrial enzymes. $P$. pulmonarius CCB20 was able to produce hydrolytic enzymes and laccase was the main oxidative enzyme produced. The isolated used in this work is a mushroom with positive characteristics such as easy cultivation and excellent adaptation. Orange waste is a cheap alternative for cultivation of mushrooms and the fungal growth caused protein enrichment of substrate. In conclusion, the cultivation of this fungus offers a way to bioconversion of lignocellulosic substrates.

\section{Acknowledgements}

This work was supported by grants from the Conselho Nacional de Desenvolvimento Científico e Tecnológico (CNPq-proc. 473181/2007-0). F.D. Inácio and R.O. Ferreira are fellowship holders of the Coordenação de Aperfeiçoamento de Pessoal de Ensino Superior (CAPES) and R.M. Peralta and C.A.V. de Araujo are fellowship holders of the CNPq.

\section{References}

[1] Alexandrino, A.M., Faria, H.G., Souza, C.G.M. and Peralta, R.M. (2007) Reutilisation of Orange Waste for Production of Lignocellulolytic Enzymes by Pleurotus ostreatus (Jack:Fr). Ciência e Tecnologia de Alimentos, 27, 364-368. http://dx.doi.org/10.1590/S0101-20612007000200026

[2] Giese, E.C., Dekker, F.H. and Barbosa, A.M. (2008) Orange Bagasse as Substrate for the Production of Pectinase and Laccase by Botryosphaeria rhodina MAMB-05 in Submerged and Solid State Fermentation. BioResources, 3, 335345.

[3] Elisashvili, V., Penninckx, M., Kachlishvili, E., Asatiani, M. and Kvesitadze, G. (2006) Use of Pleurotus dryinus for Lignocellulolytic Enzymes Production in Submerged Fermentation of Mandarin Peels and Tree Leaves. Enzyme and Microbial Technology, 38, 998-1004. http://dx.doi.org/10.1016/j.enzmictec.2005.08.033

[4] Howard, R.L., Abotsi, E., Jansen van Rensburg, E.L. and Howard, S. (2003) Lignocellulose Biotechnology: Issues of Bioconversion and Enzyme Production. African Journal of Biotechnology, 2, 602-619.

[5] Wesenberg, D., Kyriakides, I. and Agathos, S.N. (2003) White-Rot Fungi and Their Enzymes for the Treatment of Industrial Dye Effluents. Biotechnology Advances, 22, 161-187. http://dx.doi.org/10.1016/j.biotechadv.2003.08.011

[6] Souza, C.G.M., Zilly, A., Peralta, R.M. (2002) Production of Laccase as the Sole Phenoloxidase by a Brazilian Strain of Pleurotus pulmonarius in Solid State Fermentation. Brazilian Journal of Microbiology, 42, 83-90.

[7] Dumsday, G. (2008) Using Biology to Add Value to Waste Lignin Streams. Microbiology Australia, 29, 21-24.

[8] Couto, S.R. and Herrera, J.L.T. (2006) Industrial and Biotechnological Applications of Laccases: A Review. Biotechnology Advances, 24, 500-513. http://dx.doi.org/10.1016/j.biotechadv.2006.04.003

[9] Mansur, M., Arias, M.E., Copa-Patiño, J.L., Flärdh, M. and González, A.E. (2003) The White-Rot Fungus Pleurotus ostreatus Secretes Laccase Isozymes with Different Substrate Specificities. Mycologya, 95, 1013-1020. http://dx.doi.org/10.2307/3761909

[10] Reddy, G.V., Babu, P.R., Komaraiah, P., Roy, K.R.R.M. and Kothari, I.L. (2003) Utilization of Banana Waste for the Production of Lignolytic and Cellulolytic Enzymes by Solid Substrate Fermentation Using Two Pleurotus Species $(P$. ostreatus and P. sajor-caju). Process Biochemistry, 38, 1457-1462. http://dx.doi.org/10.1016/S0032-9592(03)00025-6

[11] Massadeh, M.I., Fraij, A. and Fandi, K. (2010) Effect of Carbon Sources on the Extracellular Lignocellulolytic Enzymetic System of P. sajor-caju. Jordan Journal of Biological Sciences, 3, 51-54.

[12] Vogel, H.J. (1956) A Convenient Growth Medium for Neurospora crassa. Microbial Genetics Bulletin, 13, $42-47$.

[13] Miller, G.L. (1959) Use of Dinitrosalicylic Acid Reagent for Determination of Reducing Sugar. Analytical Chemistry, 


\section{1, 426-428. http://dx.doi.org/10.1021/ac60147a030}

[14] Lenartovicz, V., Souza, C.G.M., Moreira, F.G. and Peralta, R.M. (2003) Temperature and Carbon Source Affect the Production and Secretion of a Thermostable $\beta$-Xylosidase by Aspergillus fumigatus. Process Biochemistry, 38, 17751780. http://dx.doi.org/10.1016/S0032-9592(02)00261-3

[15] Peláez, F., Martínez, M.J. and Martínez, A.T. (1995) Screening of 68 Species of Basidiomycetes for Enzymes Involved in Lignin Degradation. Mycological Research, 99, 37-42. http://dx.doi.org/10.1016/S0953-7562(09)80313-4

[16] Wariishi, H., Valli, K. and Gold, M.H. (1992) Manganese(II) Oxidation by Manganese Peroxidase from the Basidiomycete Phanerochaete chrysosporium. Journal Biological Chemistry, 267, 23688-23695.

[17] Guillén, F., Martínez, A.T. and Martínez, M.J. (1990) Production of Hydrogen Peroxide by Aryl-Alcohol Oxidase from the Ligninolytic Fungus Pleurotus erynyii. Applied Microbiology and Biotechnology, 32, 465-469. http://dx.doi.org/10.1007/BF00903784

[18] Singleton, V.L. and Rossi Jr., J.A. (1965) Colorimetry of Total Phenolics with Phosphomolybdic-Phosphotungstic Acid Reagents. American Journal Enology and Viticulture, 16, 144-158.

[19] Thaipong, K., Boonprakob, U., Crosby, K., Cisneros-Zevallosc, L. and Byrne, D.H. (2006) Comparison of ABTS, DPPH, FRAP, and ORAC Assays for Estimating Antioxidant Activity from Guava Fruit Extracts. Journal of Food Composition and Analysis, 19, 669-675. http://dx.doi.org/10.1016/j.jfca.2006.01.003

[20] Van Soest, P.J. (1963) Use of Detergents in the Analysis of Fibrous Feeds. II. A Rapid Method for the Determination of Fiber and Lignin. Journal of the Association of Official Analytical Chemistry, 46, 829-835.

[21] AOAC (1990) Official Methods of Analysis. 15th Edition, Association of Official Analytical Chemists, Arlington.

[22] Shashirekha, M.N., Rajarathnam, S. and Bano, Z. (2002) Enhancement of Bioconversion Efficiency and Chemistry of the Mushroom, P. sajor-caju (Berk and Br.) Sacc. Produced on Spent Rice Straw Substrate, Supplemented with Oil Seed Cakes. Food Chemistry, 76, 27-31. http://dx.doi.org/10.1016/S0308-8146(01)00244-8

[23] Martins, E.S., Silva, D., Silva, R. and Gomes, E. (2002) Solid State Production of Thermostable Pectinases from Thermophilic Thermoascus aurantiacus. Process Biochemistry, 37, 949-954. http://dx.doi.org/10.1016/S0032-9592(01)00300-4

[24] Cheung, L.M., Cheung, P.C.K. and Ooi, V.E.C. (2003) Antioxidant Activity and Total Phenolics of Edible Mushroom Extracts. Food Chemistry, 81, 249-255. http://dx.doi.org/10.1016/S0308-8146(02)00419-3

[25] Elmastas, M., Isildak, O., Turkekul, I. and Temur, N. (2007) Determination of Antioxidant Activity and Antioxidant Compounds in Wild Edible Mushrooms. Journal of Food Composition Analysis, 20, 337-345. http://dx.doi.org/10.1016/i.jfca.2006.07.003

[26] Grohmann, K., Manthey, J.A., Cameron, R.G. and Buslig, B.S. (1999) Purification of Citrus Peel Juice and Molasses. Journal of Agricultural Food Chemistry, 47, 4859-4867. http://dx.doi.org/10.1021/jf9903049

[27] Xavier-Santos, S., Carvalho, C.C., Bonfá, M., Silva, R., Capelari, M. and Gomes, E. (2004) Screening for Pectinolytic Activity of Wood-Rotting Basidiomycetes and Characterization of the Enzymes. Folia Microbiology, 49, 46-52. http://dx.doi.org/10.1007/BF02931645

[28] McCue, P., Horii, A. and Shetty, K. (2004) Mobilization of Phenolic Antioxidants from Defatted Soybean Powders by Lentinus edodes during Solid State Bioprocessing Is Associated with Enhanced Production of Laccase. Innovative Food Science and Emerging Technologies, 5, 385-392. http://dx.doi.org/10.1016/j.ifset.2004.05.003

[29] Vetter, J. (1986) Extracellular Cellulase and Xylanase Production of Pleurotus Species. Acta Botanica Hungarica, 32, 285-293.

[30] Haltrich, D., Nidetzky, B., Kulbe, K.D., Steiner, W. and Zupancic, S. (1996) Production of Fungal Xylanases. Bioresource Technology, 58, 137-161. http://dx.doi.org/10.1016/S0960-8524(96)00094-6

[31] Puls, J., Schmidt, O. and Granzow, C. (1987) $\alpha$-Glucuronidase in Two Microbial Xylanolytic Systems. Enzyme and Microbial Technology, 9, 83-88. http://dx.doi.org/10.1016/0141-0229(87)90147-5

[32] Makkar, R.S., Tsuneda, A., Tokuyasu, K. and Mori, Y. (2001) Lentinula edodes Produces a Multicomponent Protein Complex Containing Manganese (II) Dependent Peroxidase, Laccase and Beta-Glucosidase. FEMS Microbiology Letters, 200, 175-179.

[33] Ghosh, M., Mukherjee, R. and Nandi, B. (1998) Production of Extracellular Enzymes by Two Pleurotus Species Using Banana Pseudostem Biomass. Acta Biotechnologica, 18, 243-254. http://dx.doi.org/10.1002/abio.370180309

[34] Sherief, A.A., El-Tanash, A.B. and Temraz, A.M. (2010) Lignocellulolytic Enzymes and Substrate Utilization during Growth and Fruiting of Pleurotus ostreatus on Some Solid Wastes. Journal Environmental Science and Technology, $\mathbf{3}$, 18-34. http://dx.doi.org/10.1007/s10295-009-0620-1

[35] Kamitsuji, H., Honda, Y., Watanabe, T. and Kuwahara, M. (2004) Production and Induction of Manganese Peroxidase Isozymes in a White-Rot Fungus Pleurotus ostreatus. Applied Microbiology and Biotechnology, 65, 287-294. 
http://dx.doi.org/10.1007/s00253-003-1543-9

[36] Gonçalves, C.C.M., Paiva, P.C.A., Dias, E.S., Siqueira, F.G. and Henrique, F. (2010) Evaluation of the Cultivation of P. sajor-caju (Fries) Sing. on Cotton Textile Mill Waste for Mushroom Production and Animal Feeding. Ciência e Agrotecnologia, 34, 220-225. http://dx.doi.org/10.1590/S1413-70542010000100028

[37] Levin, L., Herrmann, C. and Papinutti, V.L. (2008) Optimization of Lignocellulolytic Enzyme Production by the White-Rot Fungus Trametes trogii in Solid State Fermentation Using Response Surface Methodology. Biochemistry Engineering Journal, 39, 207-214. http://dx.doi.org/10.1016/j.bej.2007.09.004

[38] Ferraz, A., Córdova, A.M. and Machuca, A. (2003) Wood Biodegradation and Enzyme Production by Ceriporiopsis subvermispora during Solid State Fermentation of Eucalyptus grandis. Enzyme and Microbial Technology, 32, 59-65. http://dx.doi.org/10.1016/S0141-0229(02)00267-3

[39] Masaphy, S. and Levanon, D. (1992) The Effect of Lignocellulose on Lignocellulolytic Activity of Pleurotus pulmonarius in Submerged Culture. Applied Microbiology and Biotechnology, 36, 828-832. http://dx.doi.org/10.1007/BF00172203

[40] Hofrichter, M., Vares, T., Kalsi, M., Galkin, S., Scheibner, K., Fritsche, W. and Hatakka, A. (1999) Production of Manganese Peroxidase and Organic Acids and Mineralization of ${ }^{14} \mathrm{C}$-Labelled Lignin $\left({ }^{14} \mathrm{C}\right.$-DHP) during Solid State Fermentation of Wheat Straw with the White rot Fungus Nematoloma frowardii. Applied Environmental Microbiology, 65, 1864-1870.

[41] Marzullo, L., Cannio, R., Giardina, P., Santini, M.T. and Sannia, G. (1995) Veratryl Alcohol Oxidase from Pleurotus ostreatus Participates in Lignin Biodegradation and Prevents Polymerization of Laccase-Oxidized Substrates. Journal Biological Chemistry, 270, 3823-3827. http://dx.doi.org/10.1074/jbc.270.8.3823

[42] Rodríguez, E., Nuero, O., Guillén, F., Martínez, A.T. and Martínez, M.J. (2004) Degradation of Phenolic and NonPhenolic Aromatic Pollutants by Four Pleurotus Species: The Role of Laccase and Versatile Peroxidase. Soil Biology and Biochemistry, 36, 909-916. http://dx.doi.org/10.1016/j.soilbio.2004.02.005

[43] Villena, G.K. and Gutiérrez-Correa, M. (2007) Production of Lignocellulolytic Enzymes by Aspergillus niger Biofilms at Variable Water Activities. Electronic Journal of Biotechnology, 10, 124-131. http://dx.doi.org/10.2225/vol10-issue1-fulltext-2 
Scientific Research Publishing (SCIRP) is one of the largest Open Access journal publishers. It is currently publishing more than 200 open access, online, peer-reviewed journals covering a wide range of academic disciplines. SCIRP serves the worldwide academic communities and contributes to the progress and application of science with its publication.

Other selected journals from SCIRP are listed as below. Submit your manuscript to us via either submit@scirp.org or Online Submission Portal.
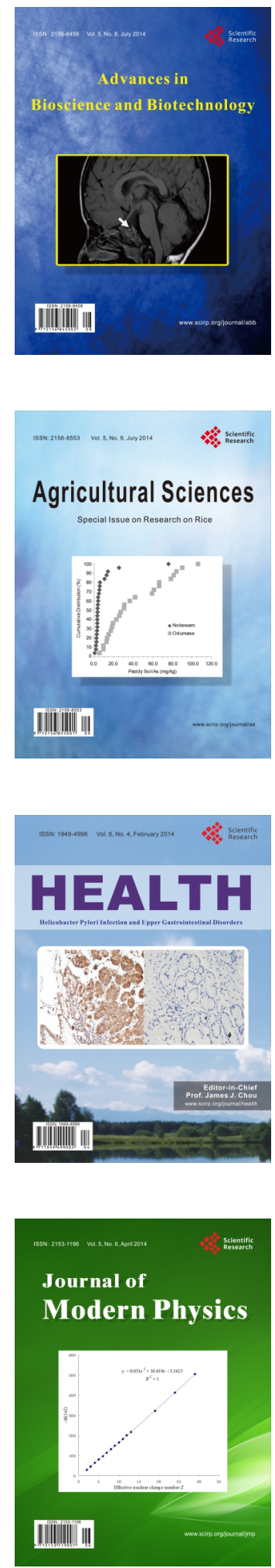
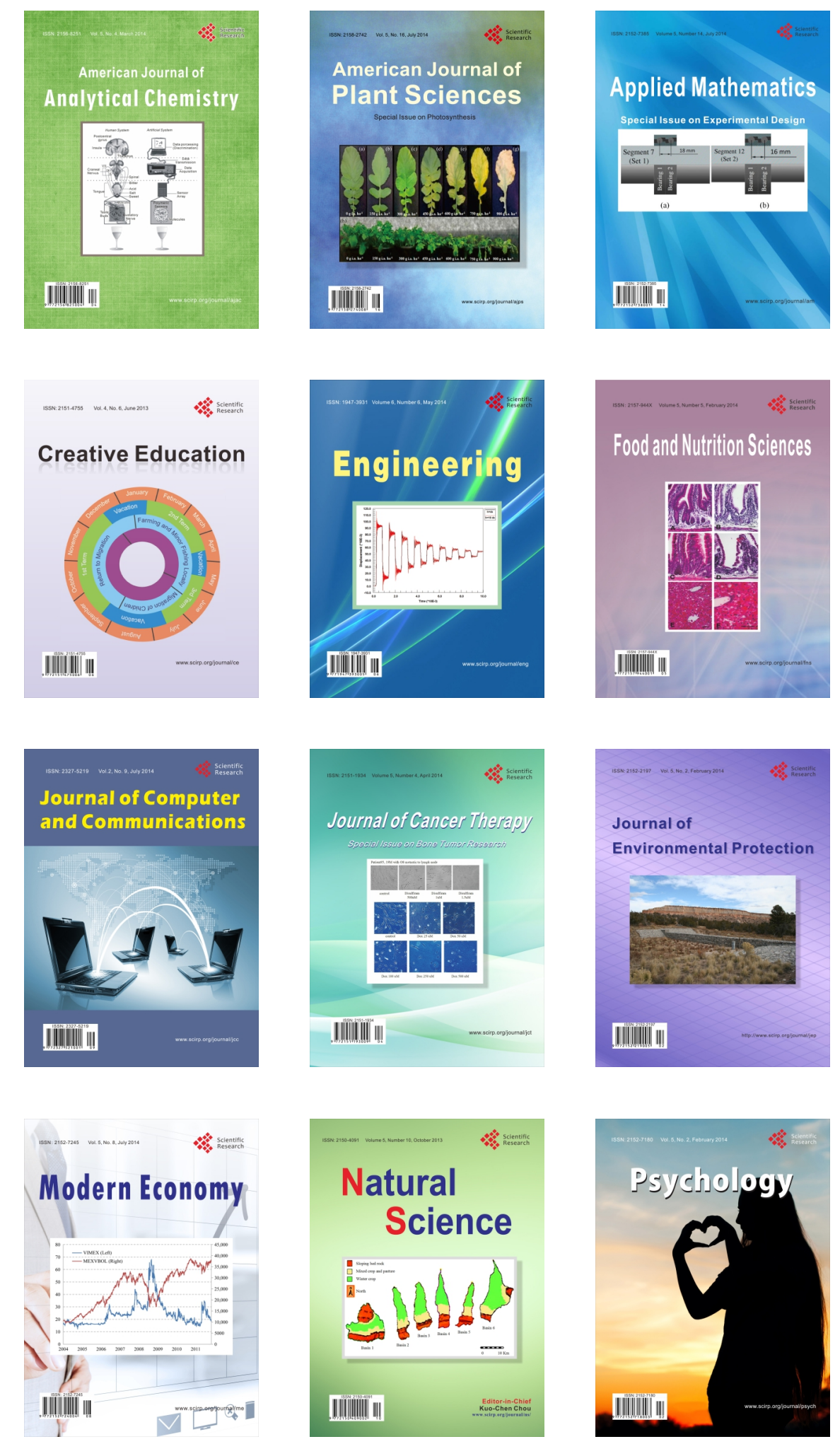